OPEN ACCESS

Edited by:

Sebastian Villasante, University of Santiago

de Compostela, Spain

Reviewed by:

Pratheesh C. Mammen,

Kerala State Disaster Management

Authority (SDMA), India

Benjamin Thompson,

Monash University, Australia

*Correspondence:

Behara Satyanarayana

satyam2149@gmail.com

Farid Dahdouh-Guebas

Farid.Dahdouh-Guebas@ulb.be

${ }^{\dagger}$ These authors share first authorship

Specialty section:

This article was submitted to

Conservation and Restoration

Ecology,

a section of the journal

Frontiers in Ecology and Evolution

Received: 26 October 2020 Accepted: 24 September 2021

Published: 21 October 2021

Citation:

Satyanarayana $B$

Quispe-Zuniga MR, Hugé J, Sulong I, Mohd-Lokman $\mathrm{H}$ and

Dahdouh-Guebas F (2021) Mangroves Fueling Livelihoods:

A Socio-Economic Stakeholder Analysis of the Charcoal and Pole Production Systems in the World's Longest Managed Mangrove Forest.

Front. Ecol. Evol. 9:621721.

doi: 10.3389/fevo.2021.621721

\section{Mangroves Fueling Livelihoods: A Socio-Economic Stakeholder Analysis of the Charcoal and Pole Production Systems in the World's Longest Managed Mangrove Forest}

\author{
Behara Satyanarayana ${ }^{1,2,3 *}$, Melissa R. Quispe-Zuniga ${ }^{2,4 \dagger}$, Jean Hugé2,4,5, \\ Ibrahim Sulong ${ }^{1}$, Husain Mohd-Lokman'1 and Farid Dahdouh-Guebas ${ }^{2,3,4 *}$
}

${ }^{1}$ Mangrove Research Unit (MARU), Institute of Oceanography and Environment (INOS), Universiti Malaysia Terengganu-UMT, Kuala Terengganu, Malaysia, ${ }^{2}$ Systems Ecology and Resource Management Research Unit, Université Libre de Bruxelles - ULB, Brussels, Belgium, ${ }^{3}$ Mangrove Specialist Group (MSG), Species Survival Commission (SSC), International Union for the Conservation of Nature (IUCN), Gland, Switzerland, ${ }^{4}$ Ecology and Biodiversity Research Unit, Vrije Universiteit Brussel-VUB, Brussels, Belgium, ${ }^{5}$ Department of Environmental Sciences, Open University of the Netherlands, Heerlen, Netherlands

The declining mangrove cover worldwide highlights the necessity of understanding the linkages between ecological and socio-economic dimensions of mangrove management. This study analyses the socio-economic aspects of the pole and charcoal production systems at Matang Mangrove Forest Reserve (MMFR), known as the world's longest managed mangrove forest, in Malaysia. We performed a socio-economic survey to identify the roles and relationships among stakeholders in the pole/charcoal production system and quantified the cash-flows in monetary value. Altogether, 160 interviews were conducted with contractors, forest officials, workers, middle-men, and consumers. The contractors are functioning as a "hub" from production to commercialization and receive major economic benefits. The commercialization of most charcoal (>80\%) aims to its exportation to Japan while the commercialization of poles is local. Although the workers' income was less than the minimum wage, they still prefer charcoal production jobs because of the availability and geographic proximity of these jobs. Our research suggests a standard salary and health insurance schemes for the workers to reduce social inequality/poverty and improve their well-being. Considering that mangroves occur in over 120 countries, our methodology can be used as a reference to unveil the socio-economic situation of mangrove-dependent communities as well as to map the economic cash-flow of the local activities that form the basis for long-term sustainable mangrove management plans.

Keywords: forest management, stakeholders, mangroves, livelihood, cash-flow

\section{INTRODUCTION}

Mangrove ecosystems that provide several ecological and socio-economic benefits (Lee et al., 2014; United Nations Environment Programme [UNEP], 2014) are declining worldwide and therefore require appropriate conservation and management (Walters et al., 2008). Besides the ecosystem services such as wood and non-wood products, 
storm protection, phytoremediation, and sediment trapping [Mcleod and Salm, 2006; Food and Agriculture Organization (FAO), 2007; Lovelock et al., 2015; Rogers et al., 2019; Wolswijk et al., 2020], mangroves also benefit the local communities as well as people living far beyond through its direct carbon sequestration and climate change regulation (Hamilton and Friess, 2018; Palacios Peñaranda et al., 2019; Jennerjahn, 2020). In the light of numerous documented human-mangrove linkages indicating a sustained dependence of coastal communities on mangrove eco-socio-economic benefits (Satyanarayana et al., 2013), decreasing forest cover (Richards and Friess, 2016), decreasing forest quality (Dahdouh-Guebas et al., 2005), and failed restoration initiatives (Elster, 2000; Kodikara et al., 2017; Lee et al., 2019), it is imperative to come up with a sustainable mangrove management policies (Lee et al., 2019). In order to maximize both the ecological and socio-economic benefits generated by mangroves, up-to-date scientific data on social-ecological system integrity (i.e., built-in relations between humans and the environment for ecosystem protection while supporting the local livelihoods) and trends is required (Costanza and Farber, 2002; Mcleod and Salm, 2006; Badola et al., 2012; Dahdouh-Guebas et al., 2021). Inclusive silvicultural practices, which involve local people in the management of mangrove resources, may lead to more sustainable management (Roy, 2016; Moreira dos Santos and Lana, 2017). The sustainability and effectiveness of mangrove management depend largely on the socio-economic conditions of the local mangrovedepended communities (Kairo et al., 2001; Sillanpää et al., 2017). Hence there is a need for investigating long-term mangrove management case-studies to document management options that do not jeopardize the livelihoods of local communities (Walters et al., 2008), as any silvicultural program begs the question for whom it is sustainable (Hugé et al., 2016).

Matang Mangrove Forest Reserve (MMFR) $\left(04^{\circ} 15^{\prime}-05^{\circ} 01^{\prime} \mathrm{N}\right.$; $\left.100^{\circ} 02^{\prime}-100^{\circ} 45^{\prime} \mathrm{E}\right)$, located in State of Perak on the west coast of Peninsular Malaysia (Figure 1), is the longest-formally managed mangrove forest and has a documented silvicultural management record since 1902 (Noakes, 1952; Abu Hassan, 1981; Ismail et al., 2005; Ariffin and Mustafa, 2013). The MMFR management is based on a 30-year rotation cycle with two thinnings (15 and 20 years after replanting) for the exploitation of poles, and with clear-felling (30 years after replanting) for charcoal production. Apart from the fishermen who depend on the MMFR for their livelihood, many villagers also rely on charcoal, and pole production systems for various jobs (e.g., tree cutter, boat driver). The charcoal produced at Matang has a large demand in the international market (e.g., Japan), and is significantly contributing to the economy of the nation with more than 11 million USD annually (Ariffin and Mustafa, 2013). Although MMFR management seems to have run successfully over the last century (Ismail et al., 2005; Wong, 2005), the socio-economic processes underpinning the commercial exploitation of the mangrove (cf. Primavera and Esteban, 2008; Feka, 2015) have not been scientifically documented.

To support mangrove ecosystem goods and services like poles and charcoal production, the broader multi-stakeholder view on the sustainability of MMFR management is a prerequisite
(Hugé et al., 2016). Although economic valuation and modeling studies on mangroves exist, particularly regarding fisheries (e.g., Grasso, 1998; Barbier and Cox, 2004; Barbier et al., 2008), to the best of our knowledge this is the first study in peerreviewed literature that unveils cash-flow between stakeholders of the mangrove poles/charcoal trade based on detailed field surveys. This research bases on the following questions: How can the role of and relationships among stakeholders involved in pole/charcoal production systems be mapped? And what are the cash-flow and benefits to the local communities through the ongoing mangrove management? Unveiling the production systems and their stakeholders in mangrove forests supports a sustainable management, ideally maintaining healthy, long-term human-mangrove linkages.

\section{MATERIALS AND METHODS}

\section{Study Area}

The MMFR-extending over $51.5 \mathrm{~km}$ on Malaysia's west coast facing the Strait of Malacca-constitutes nearly 6.98\% (40,288 ha) of the total mangrove cover in Malaysia (Jusoff, 2013; Ibharim et al., 2015; Figure 1). The reserve belongs to three administrative districts namely, Kerian, Larut, and Matang in the State of Perak (Ariffin and Mustafa, 2013; Hamdan et al., 2013). Out of 40,288 ha, nearly 30,120 ha is considered as productive forest for poles/charcoal production, while the rest is categorized into protective (formed by new, pristine and noneconomic functional forests, and used for education, ecotourism, and research), restrictive productive (formed by environmentally sensitive and marginally productive forests) and unproductive (used for agriculture bunds, house settlement and charcoal factories, pole landing sites, and fishing villages) forest types (Ariffin and Mustafa, 2013; Goessens et al., 2014).

The management of MMFR, under three administrative ranges namely, Kuala Sepetang, Kuala Trong, and Sungai Kerang (Figure 1), focuses only on Rhizophora apiculata Bl. and Rhizophora mucronata Lamk. species in the productive forest (Ariffin and Mustafa, 2013; Juliana et al., 2014; Ibharim et al., 2015), because of its high calorific value and rot resistance (United Nations Environment Programme - World Conservation and Monitoring Centre [UNEP-WCMC], 2006). Each administrative range has several concessions (108 in total for 2010-2019 period) with different-aged Rhizophora trees for the systematic and continued exploitation of greenwood (Ariffin and Mustafa, 2013; Goessens et al., 2014). The State Forestry Department of Perak releases a comprehensive 10year working plan (hereafter referred to as management plan) for Matang and allocates permissible (productive) forest land to pole/charcoal contractors (Noakes, 1952; Abu Hassan, 1981; Ariffin and Mustafa, 2013). According to the most recent management plan (2010-2019) (plan for 2020-2029 is not available for public yet), there are 70 pole contactors and 144 charcoal contractors in the vicinity. Each pole contractor receives 22.3 ha per year for thinning whereas each charcoal contractor receives 2.2-6.6 ha per year for clear felling (Ariffin and Mustafa, 2013). While they are initially given 1 year 


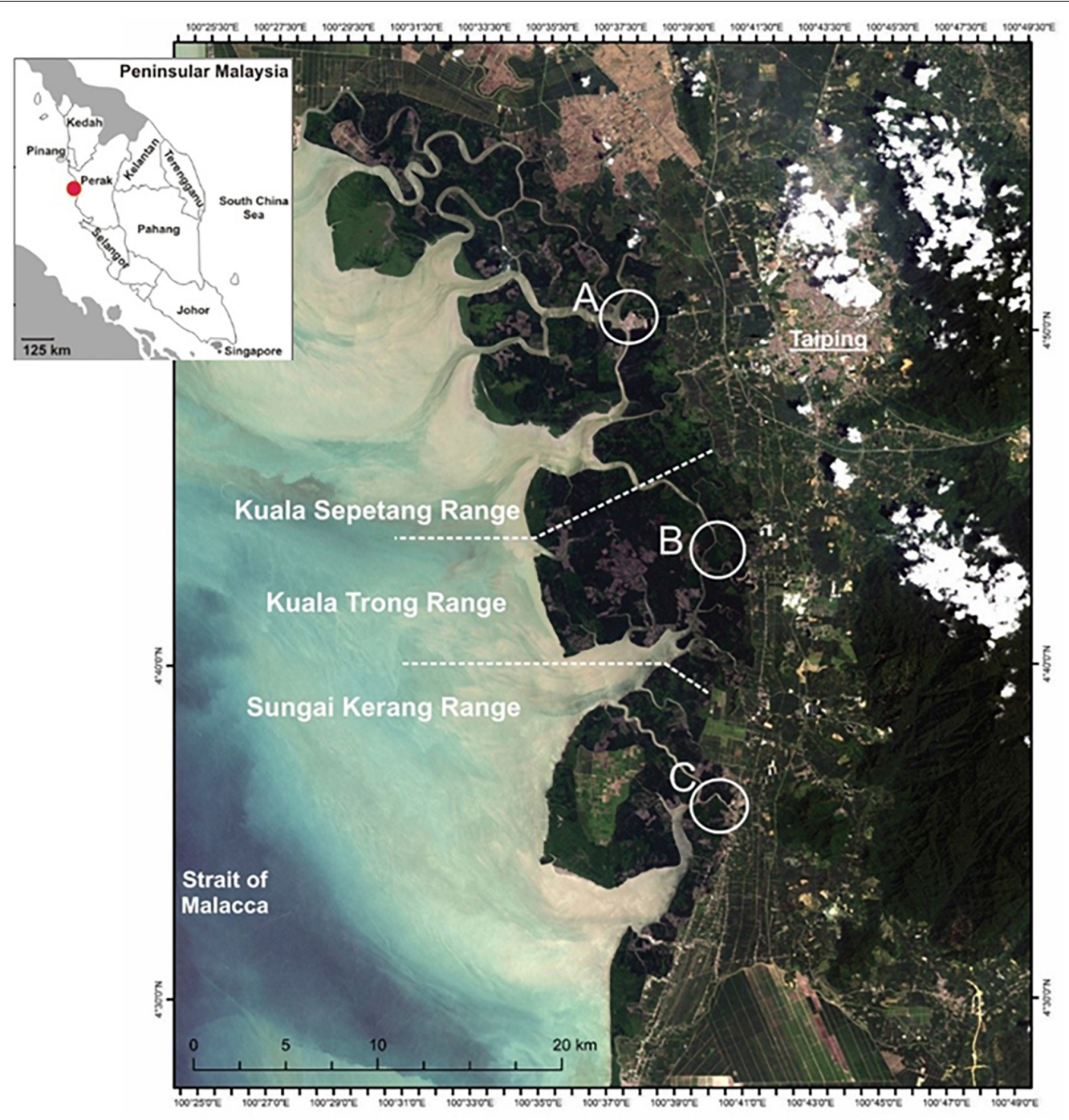

FIGURE 1 | Location of the Matang Mangrove Forest Reverse (MMFR) in the State of Perak on the west coast of peninsular Malaysia. The MMFR is managed under three administrative ranges: Kuala Sepetang (northern range), Kuala Trong (central range), and Sungai Kerang (southern range) (image source: Landsat 8 dated 17 Oct 2017 from the NASA's Earth Observatory). The white circles named (A-C) show the locations of charcoal factories (i.e., charcoal kilns) in the three forest ranges.

to clear-cut these, sequential remote sensing studies have shown that in reality it can take as long as 2 years (Lucas et al., 2020b). For 2010-2019, the MMFR management has allocated 15,837 ha for pole production (first thinning: 8,159 ha and second thinning: 7,678 ha), and 11,593 ha for charcoal production in different consessions. While mangrove poles are used locally, ca. $80 \%$ of the charcoal is exported to Japan (Chong, 2006; Ariffin and Mustafa, 2013; Jusoff, 2013). This historically rich and forestry-documented site provides an excellent background setting for carrying out this cashflow profiling study.

\section{Socio-Economic Survey Stakeholder Identification}

Firstly, the State Forestry Department provided an overview of the stakeholders involved in pole and charcoal production systems at Matang. The Forestry Department also introduced some pole/charcoal contractors who further helped us to identify other contractors, workers, middle-men and consumers available locally (Chevalier and Buckles, 2013). This research identified five types of stakeholders from all three administrative ranges of the MMFR (Table 1). The contractors have informed about their main stakeholder-the workers-via the description of the different workers' roles. Then the workers informed their duties which helped to cross-check their roles being stated by the contractors. Middle-men were identified when they come to collect pole/charcoal. There are also consumers (i.e., end users) who were identified on the basis of their daily activities e.g., charcoal consumers in the market, pole consumers in the landing site of poles. Finally, the Forestry Department is managing forest resources through plantation, thinning and clear-felling operations. However, mangrove plantation aspects 
were not covered in the present study due to the lower number of (plantation) contractors (only two people at the time of the survey) who were also found working in the charcoal factories.

Information regarding stakeholders (Supplementary Annex 1) and applicable rules/regulations (e.g., permission, licenses, government tax) to the pole/charcoal production systems were acquired through semi-structured face-to-face interviews (cf. Mukherjee et al., 2018; Young et al., 2018). The stakeholders (Table 1) in all three administrative ranges of the MMFR, based on their availability and willingness to participate in the research, were consulted for the interviews.

\section{Data Collection}

All interviewees provided their oral consent prior to answering the survey. The survey was carried out through snowball sampling (Reed et al., 2009) in Feb and Nov-Dec 2014. In total, 160 interviews-with 36 pole/charcoal contractors, 96 charcoal and 7 pole workers, 1 charcoal kiln maker, 4 middle-men, 11 consumers, and 5 State Forestry Department staff members, were conducted (Supplementary Annexes 2-7). Our sample size represents $16.8 \%$ of the total of 144 charcoal contractors in the 2010-2019 management plan. Not all charcoal contractors could be reached, as many of them have concessions in the other administrative areas (besides Kuala Sepetang), either allocated for them or under the form of cooperatives. In the case of workers, there is no official record of the actual number involved in pole/charcoal production systems. Also, we had a difficulty to reach more pole contractors due to lack of proper location for their trade (no office or working plan). The low number of pole contractor interviews was also because of their parallel role as charcoal contractors in some cases. To deal with this limitation, the interviews were carried out in the charcoal factories where the poles are unloaded from the boats. The interview questionnaires

TABLE 1 | Description of main stakeholders in mangrove pole and charcoal production systems at the Matang Mangrove Forest Reserve.

\begin{tabular}{|c|c|}
\hline Stakeholder & Description \\
\hline Contractor & $\begin{array}{l}\text { This stakeholder can be the owner or supervisor of the } \\
\text { pole/charcoal production. This person is in charge of getting } \\
\text { permission from the State Forestry Department for wood } \\
\text { extraction. }\end{array}$ \\
\hline Consumer & $\begin{array}{l}\text { The consumers are the final users of pole/charcoal. Charcoal } \\
\text { consumers could be food shop owners. Pole consumers } \\
\text { belong to the construction business. }\end{array}$ \\
\hline Middle-men & $\begin{array}{l}\text { Mainly represented by the Japanese exporter of charcoal and } \\
\text { people who sell charcoal or poles in the national market. They } \\
\text { buy poles/charcoal directly from the contractors. }\end{array}$ \\
\hline Worker & $\begin{array}{l}\text { Workers are the ones involved in the production systems in } \\
\text { return to a remunerated salary. This includes the group of tree } \\
\text { cutters, boat drivers and pole bearers in pole production } \\
\text { system and tree cutters, boat drivers, wood debarkers, log } \\
\text { bearers, log arrangers, fire monitors, charcoal bearers, packing } \\
\text { workers and lorry drivers in charcoal production system (please } \\
\text { see Supplementary Annex } \mathbf{1} \text { for their job descriptions). }\end{array}$ \\
\hline $\begin{array}{l}\text { State Forestry } \\
\text { Department }\end{array}$ & $\begin{array}{l}\text { This department provides the license to the contractor for wood } \\
\text { extraction, manages the mangrove forest, and supervises the } \\
\text { work of the contractors. }\end{array}$ \\
\hline
\end{tabular}

of this study (Supplementary Annexes 2-6) enable other researchers to replicate similar investigations elsewhere.

\section{Survey Design and Structure}

The survey was designed to elucidate the role of each stakeholder type and to map the pole/charcoal production systems and associated cash-flow. All available contractors were interviewed to get information about the production expenses and sales of pole/charcoal. Workers were interviewed to cross-check the reported economic data in production. Both these stakeholder categories were crucial for understanding the cash-flow of pole/charcoal production systems, including the number and function of the workers (Supplementary Annexes 1B,C). In addition, the workers revealed their economic status and household conditions.

Both open-ended and multiple-choice questions were used in the interviews (cf. Dahdouh-Guebas et al., 2000; Din et al., 2008). To reach as many stakeholders as possible, we interviewed the stakeholders who were readily available and accepted to participate voluntarily in our research.

\section{Data Analysis}

Survey data were analyzed by qualitative content analysis in order to elucidate the role-relationship of stakeholders in the pole/charcoal production systems (cf. Reed et al., 2009; Kustanti et al., 2014). The content analysis was based on the answers from interviews and counting the number of times the activity/worker being reported by one of the stakeholders. The differences with respect to the socio-economic background of the contractors and workers (e.g., sanitation facilities, number of dependents) were tested through Chi-square using the SPSS software. Due to the higher number of charcoal stakeholders, the income and expenses in making the charcoal (as per the feedback received from contractors, workers, and middle-men) were used to represent the cash-flow in a one-time charcoal production cycle. All data were processed in Microsoft Excel. The salary received by each worker was compared with the minimum wage announced by the Ministry of Human Resources of Malaysia (Elangkovan, 2012; Siti Marshita, 2013).

\section{RESULTS}

\section{Stakeholder Analysis}

The stakeholders and their professional linkages with mangroves have revealed their network and socio-economic dependence on the MMFR (Figure 2). The pole/charcoal contractors were found to be a key connection between the State Forestry Department and other stakeholders. The workers hailed largely from the adjacent villages and work under one or more contractors or cooperatives. Apart from the contractors and workers, other stakeholders are middle-men, consumers and State Forestry Department authorities (Figure 2). Middle-men purchase the goods and sell them in other cities/markets (in the case of poles) or export high-quality charcoal to Japan (charcoal). Some contractors also act as middle-men for local trading whereas international trading is led by two companies. In the present 


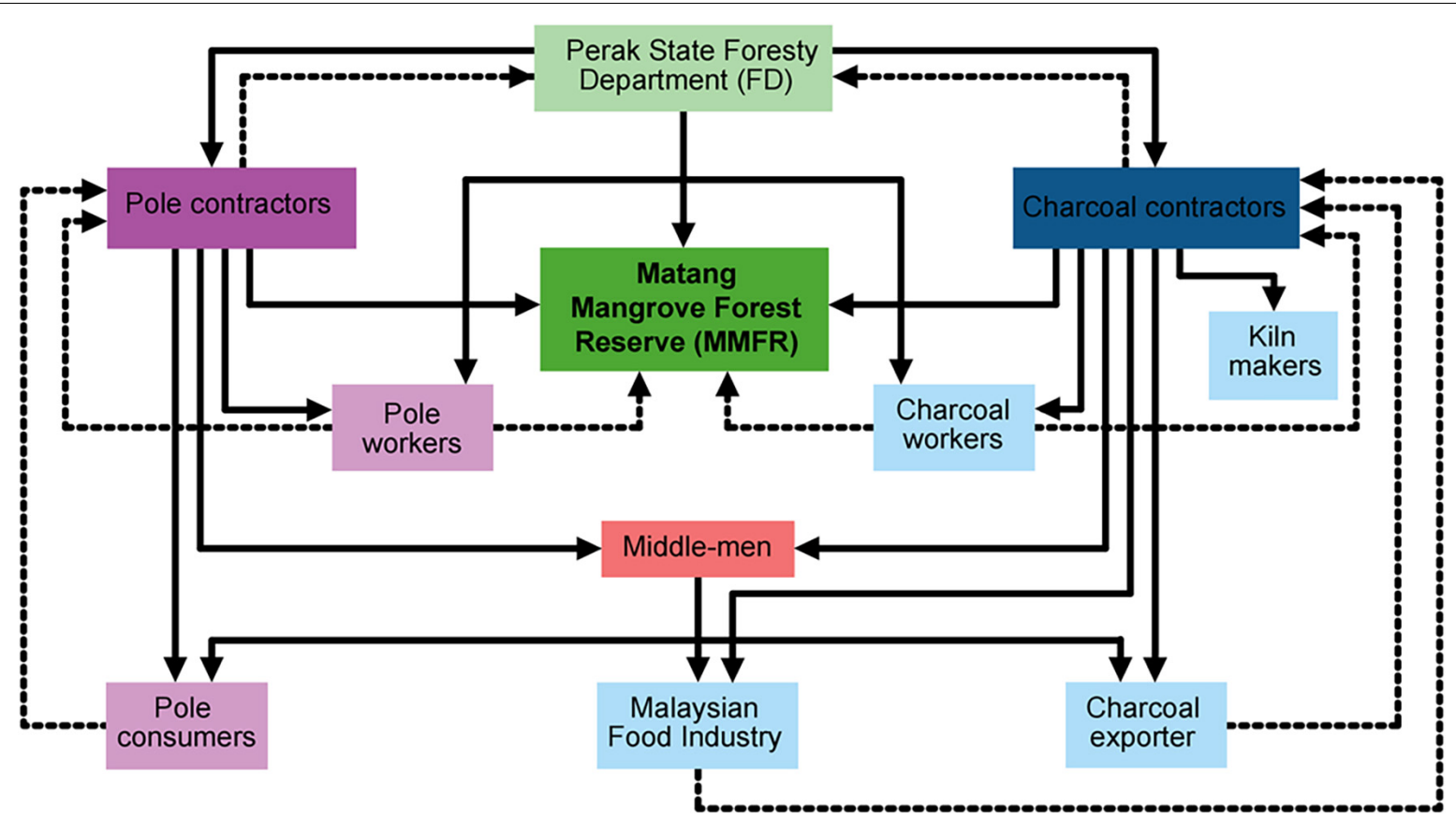

FIGURE 2 | Stakeholder network in pole/charcoal production and sales at Matang Mangrove Forest Reserve. The full arrows indicate direct influence on people (contractor-workers), purchase of products (contractor-exporter or consumers/food industry), and management decisions (State Forestry Department with MMFR/contractors). The dotted arrows show indirect influence on demand for products (consumers-contractors), worker's activities and contractor's attitude for increasing greenwood allocation.

study, only one company has accepted to conduct the interviews with their staff. In the case of middle-men for mangrove poles, we found them as lorry/mini truck drivers who were hired by the consumers in other states of Peninsular Malaysia. Finally, the State Forestry Department authorities supervise all the activities ranging from allocation of the forest area to contractors for thinning, clear-felling and propagule stocking in clear-felled areas to enforcement of the regulations (i.e., fining the misbehaved contractors).

\section{Mangrove Pole Production}

The pole production process (Figure 3A) starts with a license from the State Forestry Department through an open tender system. The mangrove poles are grouped into four diameter classes and sold at different lengths (Table 2). The pole contractor who received the license for first thinning is likely to have the same area for second thinning after 5 years to enable a selfcontrolled thinning. Each pole contractor hires 2-3 tree cutters to obtain 50-60 poles per day. Once the number of poles reaches the capacity of a boat (ca. 250-300 poles), the contractor hires a boat driver to send them to the shore. Approximately, 2,097 poles are extracted from 22.3 ha of the productive forest in Matang. The poles are usually left outside in the open landing areas near charcoal factories (no storehouse). The middle-men purchase poles from the contractors and transfer them to their places in private vehicles (e.g., lorry/mini truck). For loading the poles into vehicles, the middle-men hire 1-2 pole bearers. Sometimes, upon receiving the purchase order from a consumer, the contractor will look after both transport and loading arrangements on behalf of the consumer.

\section{Mangrove Charcoal Production}

Typically, the clear-felling operation of 6.6 ha in 30-year old mangrove forest goes on for nearly one year. During this process (Figure 3B), each contractor hires $2-3$ tree cutters to cut down the trees into $1.6 \mathrm{~m}$ logs (each log weighs about $60-70 \mathrm{~kg}$ ). The cutters also help to remove the bark (debarking), if requested by the contractor. The boat driver will transfer the greenwood from the forest to the charcoal factory. All charcoal factories are located on the landward side (in the area leased by the State Forestry Department), but adjacent to the water channels accessible by boat during the high tide. Log bearers will shoulder-carry the logs from boat/shore to the kiln and pile them vertically. Once the kiln is ready, the log arrangers will arrange them inside the kiln

TABLE 2 | Price of Rhizophora poles obtained from the Matang Mangrove Forest Reserve in the local market ( 1 USD $=3.27 \mathrm{MYR}$ ) $(n=7$ pole contractors).

\begin{tabular}{rllll}
\hline & \multicolumn{5}{c}{ Stem diameter (cm) } \\
\cline { 2 - 5 } & $\mathbf{5 - 6}$ & $\mathbf{7 - 8}$ & $\mathbf{1 0 - 1 1}$ & $\mathbf{1 2 - 1 3}$ \\
\hline Pole lenght (m): 5-4 & 1.38 USD & 1.70 USD & 1.88 USD & 2.49 USD \\
$4-3$ & - & - & 2.55 USD & 2.38 USD \\
$3-2$ & - & - & 2.91 USD & - \\
\hline
\end{tabular}

"-" no reported data, because these sizes would not be saleable. 

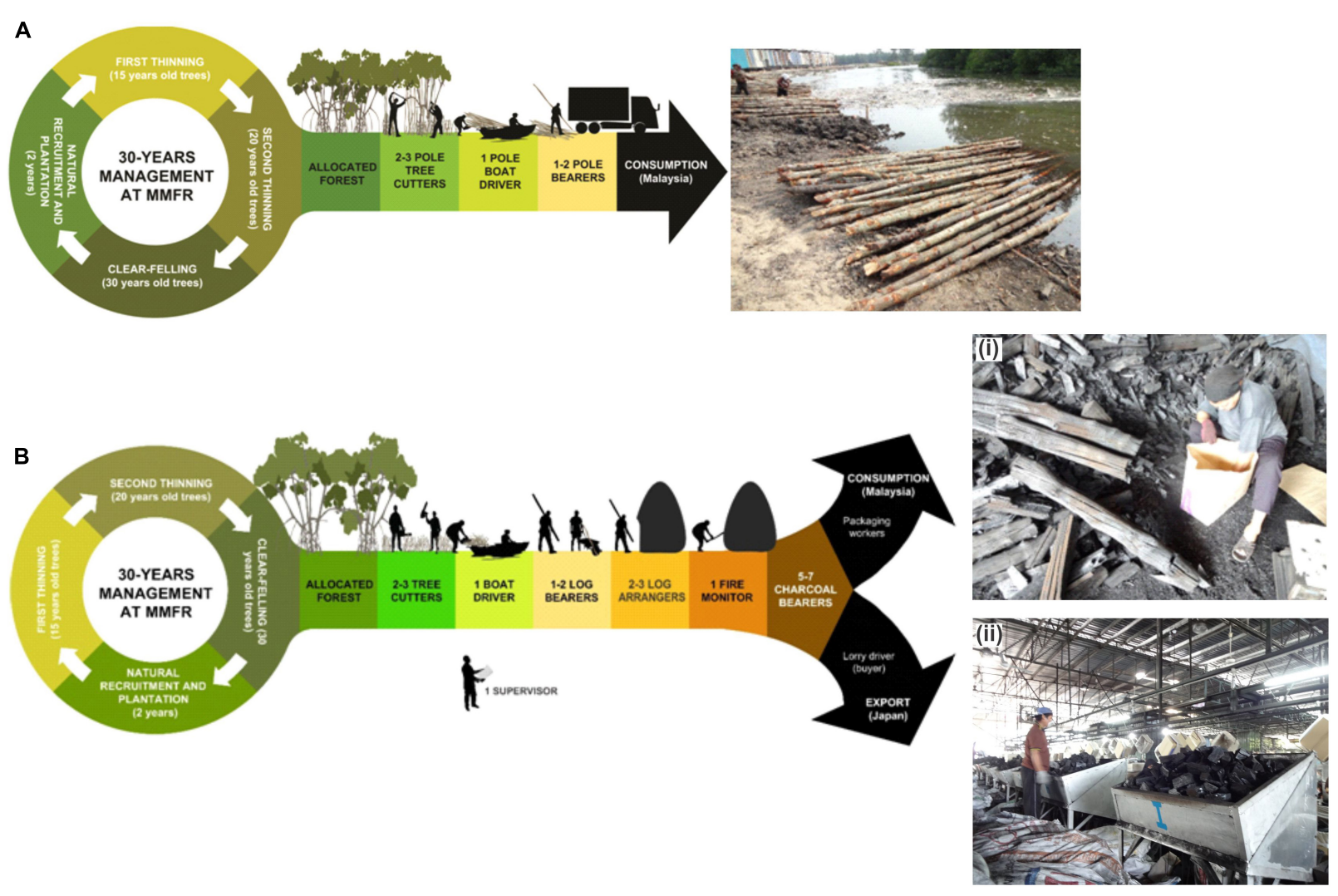

FIGURE 3 | Pole and charcoal production systems at the Matang Mangrove Forest Reserve-Process of mangrove pole extraction (i.e., thinning) (A), and of charcoal production (B) with different workers engaged in various tasks. The photographs show Rhizophora poles at the landing site near a charcoal factory (A); the charcoal packing for local markets in Malaysia (B-i) and the charcoal packing for export to Japan (B-ii).

which can accommodate 1,000-1,200 logs. When the kiln is full, the fire monitor starts the conversion of greenwood into charcoal in three stages by controlling the intensity of the fire as large (stage-I), small (stage-II), and cooling/sealed kiln (stage-III). This conversion process spans between 28 and 45 days, depending on the smell and color of the smoke and the arrangement of logs (pers. comm. with fire monitors). Once the charcoal is produced, the charcoal bearers load them into a vehicle that belongs to the middle-men (e.g., exporters). A small fraction of the charcoal (ca. 20\%) will be packed for local markets by the packing workers. The local consumption of charcoal is mostly confined to the workers and the contractors, along with a few roadside food shop vendors.

\section{Cash-Flow Dynamics in Mangrove Pole and Charcoal Production Systems}

Each pole contractor pays 1,529.05 USD to the Forestry Department for a 6-month (renewable) thinning license in 15 or 20-year-old forest. For thinning, the tree cutters are paid in relation to pole length and diameter (payment details in Table 3 ). The payment to a boat driver (to bring poles to the shore) is about $0.15 \mathrm{USD} /$ pole if the contractor pays for boat diesel and otherwise $0.24 \mathrm{USD} /$ pole. To load poles into middle-men vehicles, the pole bearers are paid $0.07 \mathrm{USD} /$ pole. Overall, the cost of mangrove pole production (taking into account 2,097 poles from $22.3 \mathrm{ha}$ ) fluctuates from 1,425.96 USD for the smaller size (2.74 m length and $10.16 \mathrm{~cm}$ diameter) to $1,698.74$ USD for the bigger size (4.88 $\mathrm{m}$ length and $12.7 \mathrm{~cm}$ diameter). On the other hand, the net profit for pole contractors could reach up to 1,467.90 USD (market sale: $2,893.86$ USD) for the smaller size and 4,403.53 USD (market sale: $6,102.27$ USD) for the bigger size poles.

In the case of charcoal, both production cost and retail prices (i.e., middle-men payment to the contractor) are complex (Figure 4). Each charcoal contractor receives a 1-year (renewable)

TABLE 3 | Payment for the workers to cut and obtain Rhizophora poles from the Matang Mangrove Forest Reserve ( 1 USD = 3.27 MYR) in 2014 ( $n=12$, including workers and contractors).

\begin{tabular}{lcccc}
\hline & \multicolumn{4}{c}{ Stem diameter $(\mathbf{c m})$} \\
\cline { 2 - 5 } & $\mathbf{5 - 6}$ & $\mathbf{7 - 8}$ & $\mathbf{1 0 - 1 1}$ & $\mathbf{1 2 - 1 3}$ \\
\hline Pole lenght $(\mathrm{m}):$ 3-2 & 0.37 USD & 0.43 USD & 0.38 USD & 0.46 USD \\
4-3 & - & - & 0.49 USD & 0.49 USD \\
Without considering the & - & 0.41 USD & 0.44 USD & 0.50 USD \\
length & & & & \\
\hline
\end{tabular}

"-" no reported data, because these lenghts would not be saleable. 


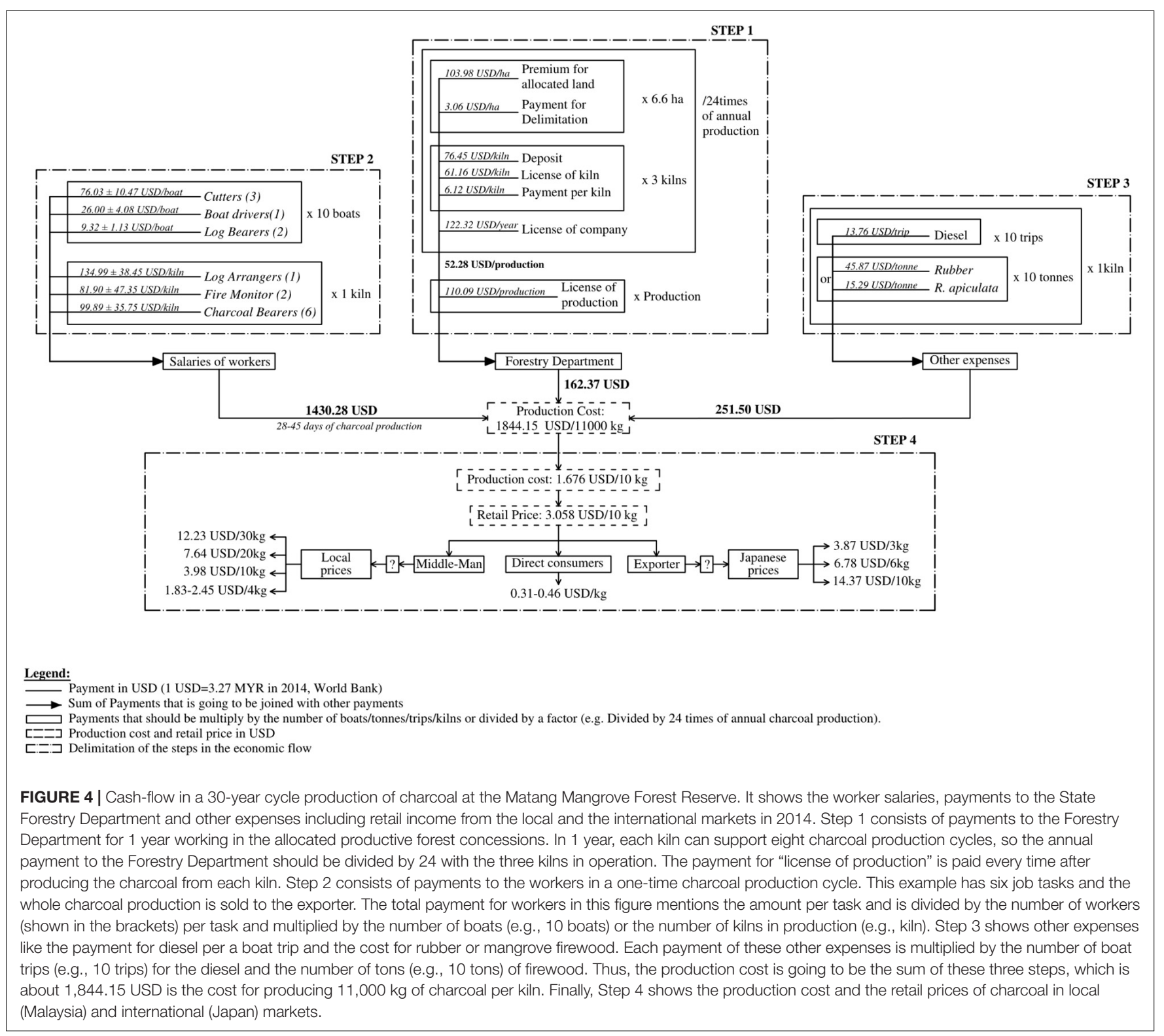

license to clear-fell the 30-year-old trees. This license allows the contractor to use three charcoal kilns and have $2.2 \mathrm{ha} / \mathrm{kiln}$. So, the contractor with a 1-year license may have 6.6 ha of greenwood and three kilns. For this 1-year license, the contractor pays: (i) 122.32 USD for tree cutting license, (ii) 686.3 USD for premium tax, (iii) 20.2 USD for harvest area delimitation, (iv) 183.48 USD for kilns operation license, (v) 18.36 USD for each kiln payment, (vi) 110.09 USD for a production license, and (vii) 229.35 USD as security deposit (Forestry Department refunds this amount after the logging is satisfactorily completed) (Figure 4). In addition, the contractor bears the cost of 251.5 USD for firewood and diesel (to burn logs inside the kiln) and 1,430.28 USD for workers' salary per working kiln. In some cases, the contractor hires 12 wood debarkers by paying $0.05-0.09$ USD per a debarked log at the place of their charcoal factory. The packed charcoal for local markets is sold for 0.05-0.06 USD per pack. Since exporters are reluctant to inform their profit margins, the retail prices of charcoal in the Japanese market were investigated through online information. Overall, the cost for producing $11,000 \mathrm{~kg}$ of charcoal (one-time kiln production) was estimated to be 1,844.15 USD (1 $\mathrm{USD}=3.27$ MYR in 2014).

\section{Demographic Information}

Most interviewed charcoal contractors are males (only two female contractors). Likewise, there were more male workers than female workers in the pole/charcoal production systems at MMFR (Table 4). The MMFR is considered as a key income source and welfare for local families. In 2014, about $92.47 \%$ of workers claimed themselves as main support to their families. The number of family relatives depending on contractors was more than to the workers $\left(\chi^{2}\right.$ correct $=16.045, \chi^{2}$ critic $=6.64$, d.f. $=1, p<0.01$ ). About $71 \%$ of workers do only one job (a 
TABLE 4 | Demographic information based on the interviews $(n=96)$ conducted with charcoal production workers at the Matang Mangrove Forest Reserve, 2014.

\begin{tabular}{lll}
\hline & Number of respondents & $\%$ \\
\hline Income for family & 68 & 71 \\
One task & 28 & 29 \\
Multitasks & & \\
Gender & 71 & 74 \\
Male & 25 & 26 \\
Female & & \\
Extra-income & 12 & 55 \\
Related to mangroves & 10 & 45 \\
Non-related to mangroves & & 19 \\
Education & 18 & 10 \\
No report* & 10 & 38 \\
No studies & 36 & 33 \\
Primary Diploma & 32 & \\
Secondary Diploma & &
\end{tabular}

*Not reported by workers.

single task in the charcoal production system) while the rest were involved in multiple tasks (e.g., crab catch, fishing, market stall, palm oil plantation) to increase their family income. Regarding education, $71 \%$ of workers received primary or secondary education (Table 4). In terms of house sanitation, most workers had only outdoor toilets compared to the interviewed contractors $\left(\chi^{2}\right.$ correct $=31.46, \chi^{2}$ critic $=6.64$, d.f. $\left.=1, p<0.01\right)$.

In charcoal production, the income of several workers was found to be less than the official minimum wage (Figure 5). Some workers have other jobs which are not related to charcoal production (e.g., food business). During the interviews, we found that $100 \%$ of tree cutters, $90.91 \%$ of boat drivers, $46.15 \%$ of $\log$ bearers, $50 \%$ of wood debarkers, $42.86 \%$ of log arrangers, $41.67 \%$ of fire monitors, $16.67 \%$ of charcoal bearers, and $62.50 \%$ of packing workers work only in their respective tasks without having any income from other jobs. Out of 96 interviews held with the workers, only five respondents' salary details were in agreement with the amount claimed by the contractors as a payment to the workers. The taxes paid by the contractors to the State Forestry Department are, however, in accordance with the recent (2010-2019) management plan.

\section{DISCUSSION}

\section{Matang for Stakeholders' Livelihood}

Sustainable mangrove management is interpreted in different ways by different stakeholders, yet in the case of Matang, all stakeholders at least seem to appreciate the focus on silvicultural management aimed at producing poles and charcoal. This was confirmed by the present study and is in line with the dominant mangrove management discourses identified by Hugé et al. (2016), in which stakeholders express a preference for business as usual and/or prudent reform strategies. However, the economic importance of the pole/charcoal business generates pressure to increase the productive forest area when the 10 -year management plan is periodically re-drafted (pers. conv. with State Forestry Department). For instance, the number of charcoal contractors and kilns were raised by $40-67 \%$ between the two management plans of 2000-2009 and 2010-2019 (Ariffin and Mustafa, 2013).

The logic of providing the same forest concessions to the same pole contractor for both first and second thinning not only enhances self-regulation among them but also encourages the contractors to complete their job responsibly. Good conduct (e.g., not to cut the mangrove mother trees chosen by the State Forestry Department), as well as work efficiency (e.g., completion of thinning within 6 months of license) by the contractors, are important for fulfilling their license agreement with the State Forestry Department. In addition, regular demand and guaranteed sales keep the pole contractors to follow the norms of thinning, especially on the cutting time. Although poles are not the main product of the MMFR, the timing of the two thinnings is still a point of discussion (FontalvoHerazo et al., 2011; Goessens et al., 2014). In some countries like Kenya, The Gambia and Cameroon, a conditional market where pole production depends on the demand for house construction and firewood (Dahdouh-Guebas et al., 2000; Atheull et al., 2009; Satyanarayana et al., 2012). Despite the limited number of interviews held with workers and pole contractors, we managed to identify their socio-economic roles efficiently due to less complexity of the subsystem. Although the profitable range of the pole production (1,467.90-4,403.53 USD) seems to be reasonable, it is still low for a 6-month job and mainly depends on the size/diameter of the poles acquired from different concession areas with different productivity. Therefore, the pole contractors participate in other jobs such as mangrove plantation, etc. in the vicinity. In addition, the involvement of more male workers in the pole/charcoal production systems can be explained by the fact that the majority of the pole/charcoal-related jobs require physical strength. Gender-based division of tasks can further be explained by local customs and marital status (Amin and Alam, 2008). A gender division of labor where the men are involved mostly in mangrove fishery or wood harvesting activities and the women in household subsistence collection, food preparation, etc., was also evident from Sri Lanka and Cameroon (Satyanarayana et al., 2013; Feka, 2015).

Regarding the charcoal consumers, the main reason for not having many local users is because of the availability of subsidized propane gas cylinders in the market (each $14 \mathrm{~kg}$ cylinder $=28$ MYR i.e., ca. 8.56 USD in 2014). The most common charcoal consumers are the food shop owners (e.g., barbeque-called "laksa" in Bahasa Melayu) who consider charcoal as more economical for their business. Moreover, they believe that flavor and taste upon cooking with the mangrove charcoal are better than gas-based cooking. Earlier, Satyanarayana et al. (2013) also found the mangrove fuelwood users with the same perceptions in Sri Lanka. In addition, the remaining biomass of clear-felling and thinning is already used by the contractors (e.g., firewood of kilns), reducing the possibility to produce biochar. In Malaysia, biochar-used as a carbon sink and soil enrichment for increasing crop productivity-is mainly produced in palm oil plantations due to its high waste biomass (Mašek, 2013; Kong et al., 2014). Malaysian charcoal factories are largely dependent on Japan for 


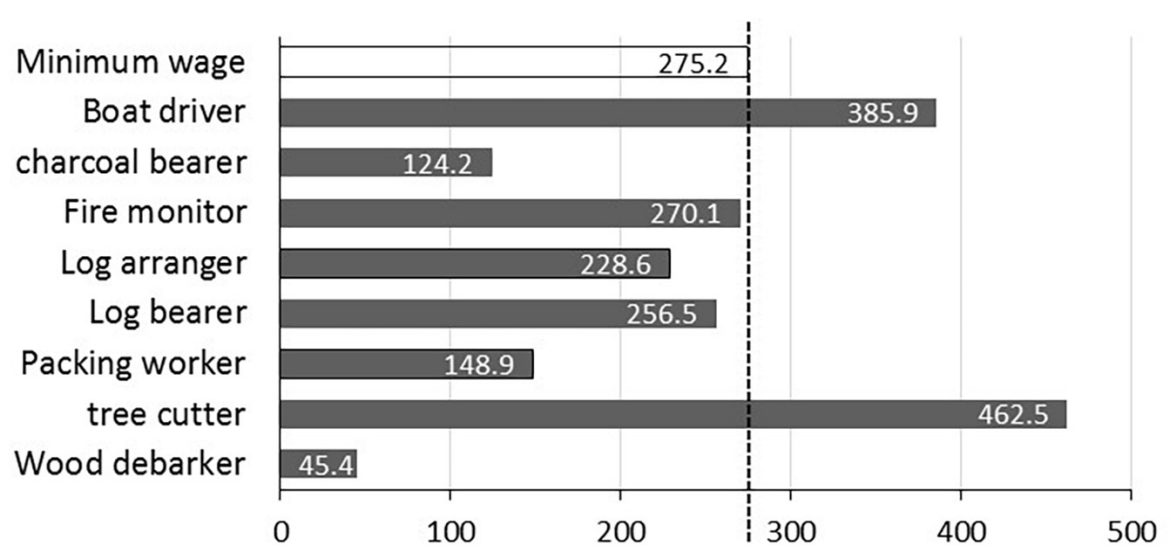

FIGURE 5 | Monthly income (in USD) of charcoal workers at the Matang Mangrove Forest Reserve $(n=96)$ in 2014. Income below the dotted line represents a salary which is lower than the minimum wage put forward by the government in Peninsular Malaysia.

a continuous demand for charcoal (Ariffin and Mustafa, 2013). Neither market fluctuations (mostly short-term) nor natural disasters (i.e., tsunamis and earthquakes) in Japan affected the charcoal business so far (pers. comm. with exporters). Moreover, the retail price of charcoal to the export companies at 3.058 USD $/ 10 \mathrm{~kg}$ is empowering contractors with a profit margin of $82.46 \%$ compared to the production cost of $1.676 \mathrm{USD} / 10 \mathrm{~kg}$ (Figure 4). In terms of cash equivalent transactions, the workers in the charcoal factory occasionally receive a few kilograms of charcoal as gift from the contractors. Besides the charcoal production, contractors also manufacturing a few other charcoalderived products such as vinegar, soap, souvenirs, insecticides, etc. to increase their income. Overall, charcoal production is a profitable business and hence many contractors are following their ancestral footsteps and continuing it from generation to generation. This would also justify the dual role of some people as both pole and charcoal contractors at Matang.

The workers still prefer to depend on pole/charcoal activity, despite their lower income than the monthly minimum wage of 900 MYR (275.22 USD) in 2012 (Elangkovan, 2012; Siti Marshita, 2013), due to the closeby workplace and availability of jobs. Only tree cutters and boat drivers are paid more, probably due to their long stays inside the forest. Outdoor toilets at the worker's homes might also reflect their poor economic situation/living conditions in the vicinity of MMFR.

\section{Sustainability of the Mangrove Trade}

In the pole/charcoal production systems, an understanding of the respective position and power of stakeholders is relevant to support the sustainability of MMFR. Our stakeholder analysis has identified that all stakeholders involved in these production systems, with their professional linkages and activities, depend on mangroves for their livelihoods. In addition, similar to other studies (Moriizumi et al., 2010; Feurer et al., 2018), this study has found that MMFR via its management provides job opportunities to local stakeholders. Due to such socio-economic importance, proper management of the mangrove ecosystems is highly essential (Aheto et al., 2016; Nguyen et al., 2017).
In fact, the MMFR was said to be a global reference point for others to learn different mangrove conservation strategies (Goessens et al., 2014; Rahman and Asmawi, 2016). However, Goessens et al. (2014) expressed the need for assessing ecological redundancy and resilience due to monoculture (Rhizophora) plantations, valuing of wood extraction through socio-economic surveys, etc., to help the ongoing management at MMFR to be sustainable. Recently, Martínez-Espinosa et al. (2020) have stated that the managers should also consider biodiversity accounts of the mangrove-associated fauna seriously (e.g., monitoring of bird populations, micro- and macrobenthos, etc.). The ongoing forest rotation measures not only affect the animal habitats, but also limit their role in import and export of C-compounds and non C-resources, tropic-level transfers, etc. (Dahdouh-Guebas et al., 2021). In addition, for mangroves in general, Cannicci et al. (2021) expressed similar concerns about the low functional redundancy in invertebrates in certain areas of the world, specifically where tree species diversity is low.

To our knowledge, the present study is one of the firsts of its kind, if not the first: it discloses the entire cash-flow of silvicultural management in a mangrove forest, here in MMFR. By considering all possible routines in the pole/charcoal production systems, we believe that the present cash-flow is authentic and provides a reliable picture and baseline for Matang. After witnessing the pole/charcoal production since the beginning of the twentieth century (Lucas et al., 2020a), sustainable silviculture with higher biomass (Goessens et al., 2014), a steady increase in the mangrove trade profits (Ariffin and Mustafa, 2013), etc., it is possible to conclude that the cash-flow dynamics presented in this study are benefiting the local stakeholders, but whether it is sustainable or not can only be assessed sequentially. Community-based management has undoubtedly proven too often be a good choice for mangrove ecosystems on which local people are dependent, but these stakeholders must be considered and consulted (Stone et al., 2008; Satyanarayana et al., 2012, 2013). For instance, the differences in the workers' salaries paid by the contractors suggest the need for a standard salary scheme that is not less than 
the minimum wages upgraded by the Malaysian government (Ministry of Human Resources [MHR], 2020). Revised salaries in pole/charcoal production systems could reduce social inequality and poverty among the workers (cf. Thorat, 2014). This study can also be used as a base for monitoring the involved stakeholders to ensure better working and health conditions. The poor working conditions such as dust, smoke, and heat in the charcoal factories are likely to affect the health of the workers. Therefore, worker's health needs to be included for the improvement of the MMFR management and offer them possible health insurance policy in the near future. On the other hand, no relevant publications are available to compare the present economic details widely. Although we found that mangroves at Bintuni Bay (Indonesia) are managed for chipwood production based on 25-year rotation cycle, the researchers (e.g., Sillanpää et al., 2017) informed only about the forest structure, complexity, biodiversity, and sustainability issues. The present study therefore sheds new light on the importance of cash-flow profiling studies in mangrove trade and encourage others to pursue the same elsewhere.

The future sustainability of the mangrove trade depends on extreme weather events that are linked to climate change, cyclones/tsunamis, coastal erosion, diebacks, etc., which are all beyond the control (DasGupta and Shaw, 2017; Sippo et al., 2020). The "restrictive productive forest" (ca. 2,743 ha) in MMFR is only to support small-scale disturbances under the normal conditions i.e., for allocation of new concessions to the contractors if they come across periods of lower productivity, more lightning strikes, etc., in the thinning or clear-felling sites (Ariffin and Mustafa, 2013). Since the accelerating climate change and other natural calamities have far-reaching impacts on local biodiversity and forest cover, thorough scientific investigations are required to pre-plan for worst-case scenarios at the Matang. Adaptive management and stewardship for imminent change in uncertain times are paramount in the "survival" of ecosystems (Dahdouh-Guebas et al., 2021) and initiatives such as the Red List of Threatened Ecosystems can help in this exercise (Keith et al., 2013; Sievers et al., 2020). Although mangroves can slow down the process of climate change due to high carbon sequestration potential (Palacios Peñaranda et al., 2019; Jennerjahn, 2020), the gain and loss of carbon due to 30-year forest rotation cycle is still a point of concern. Under these circumstances, the Forestry Department is advised not to increase the number of pole/charcoal contractors-one way to minimize the pressure on productive forest and another way to face less consequences if climate change and/or other natural perturbations are inescapable in the near future.

\section{Limitations and Future Recommendations}

Since the socio-economic surveys are entirely depending on the information given by stakeholders, there are chances to miss a few inflow and outflow estimates. Although charcoalderived products like vinegar, soap, souvenirs, insecticides, etc., are not part of the MMFR management, future studies could analyze its cash-flow and incorporate them as sub-products of the charcoal production system. While the minimum wage of the workers was raised from 900 to 1,200 MYR ( 290.00 USD) in 2020 (Ministry of Human Resources [MHR], 2020), it is still uncertain whether all pole/charcoal workers are paid accordingly or not due to no current observations. The rolerelationship among stakeholders, including cash-flow in the MMFR social-ecological system, can be used as a framework for forest sustainability assessments in Malaysia as well as in other countries. There are only a few other countries like Indonesia, Thailand, and Vietnam that practice a documented mangrove charcoal production (under different management regimes) and hence replicability of the present work is perhaps limited. However, it can be replicated in areas where indigenous people and/or traditional lifestyles depend on mangrove goods being traded, and equivalent interview surveys could highlight areas where they are bartered. Despite being time-consuming, interviews provide direct information from the stakeholders (Mukherjee et al., 2018; Young et al., 2018), and is an affordable technique that can be applied in all mangrove and non-mangrove areas for the socio-ecological assessments.

\section{CONCLUSION}

The socio-economic insights are key to understand and improve the management of mangrove ecosystems, particularly for Matang Mangrove Forest Reserve (MMFR) where management has been documented in forestry records for over a century. Ensuring sustainable management of the forest and feedstock for charcoal requires all stakeholders to acknowledge the plurality of the concept of sustainability, not only in MMFR but in the global south in general (cf. The Charcoal Project [TCP], 2021). Despite the long-term silvicultural management history of the MMFR, the present study unveiled the relationships among stakeholders, along with a cash-flow analysis of the mangrove pole/charcoal production systems for the first time. From the observed economic transactions in the mangrove commercial exploitation, the contractors-functioning as a "hub" from production to the commercialization of the pole/charcoal-are the main economic beneficiaries of the ongoing management. However, the charcoal business (with a profit margin over $80 \%$ ) is more lucrative than the pole business and therefore several contractors are engaged in both professions for ages. A consistent yield and quality from the rejuvenating productive forest are justifying high demand for the Matang charcoal in overseas markets (Japan), which in turn is also contributing to the economy of the nation significantly. The cash-flow dynamics in this study are also suggestive of benefiting the local stakeholders sustainably. On the other hand, a standard salary scheme and health insurance policy are inevitable for the workers to reduce social inequality/poverty and improve their well-being. In light of the limited number of interviewsespecially with middle-men and consumers, we expect a wider range in the cash-flow values that we identified. Overall, the key findings of this novel study are useful to take necessary measures for enhancing the ongoing MMFR management and maintain a healthy human-mangrove linkage and to instill long-term sustainability and keep fuelling livelihoods. 


\section{DATA AVAILABILITY STATEMENT}

The raw data supporting the conclusions of this article will be made available by the authors, without undue reservation.

\section{ETHICS STATEMENT}

The studies involving human participants were reviewed and approved by the Forestry Department Peninsular Malaysia Ministry of Natural Resources and Environment. The participants provided their informed consent to participate in this study.

\section{AUTHOR CONTRIBUTIONS}

MQ-Z, BS, and FD-G conceived and designed the experiments. MQ-Z performed the experiments. MQ-Z and FD-G analyzed the data. FD-G, JH, BS, HM-L, and IS contributed to reagents, materials, and analysis tools. MQ-Z, BS, JH, and FD-G wrote the manuscript. FD-G, BS, HM-L, and IS supervised the research. $\mathrm{JH}$ provided background data. HM-L and IS provided logistical support. All authors Provided substantial revisions.

\section{REFERENCES}

Abu Hassan, H. H. (1981). A Working Plan for the Second 30-Year Rotation of the Matang Mangrove Forest Reserve Perak. The first 10-year period 1980-1989. Italy: Food and Agriculture Organization of the United Nations.

Aheto, D. W., Kankam, S., Okyere, I., Mensah, E., Osman, A., Jonah, F. E., et al. (2016). Community-based mangrove forest management: implications for local livelihoods and coastal resource conservation along the Volta estuary catchment area of Ghana. Ocean Coast. Manag. 127, 43-54. doi: 10.1016/j.ocecoaman. 2016.04.006

Amin, S., and Alam, I. (2008). Women's employment decisions in Malaysia: does religion matter? J. Socio. Econ. 37, 2368-2379. doi: 10.1016/j.socec.2008.04.012

Ariffin, R., and Mustafa, N. M. S. N. (2013). A Working Plan for the Matang Mangrove Forest Reserve, Perak 6th Edn. Malaysia: Perak State Forestry Department.

Atheull, A. N., Din, N., Longonje, S. N., Koedam, N., and Dahdouh-Guebas, F. (2009). Commercial activities and subsistence utilization of mangrove forests around the Wouri estuary and the Douala-Edea reserve (Cameroon). J. Ethnobiol. Ethnomed. 5:35. doi: 10.1186/1746-4269-5-35

Badola, R., Barthwal, S., and Hussain, S. A. (2012). Attitudes of local communities towards conservation of mangrove forests: a case study from the east coast of India. Estuar. Coast. Shelf Sci. 96, 188-196. doi: 10.1016/j.ecss.2011.11.016

Barbier, E. B., and Cox, M. (2004). An economic analysis of shrimp farm expansion and mangrove conservation in Thailand. Land. Econ. 80, 389-407. doi: 10.2307/ 3654728

Barbier, E. B., Koch, E. W., Silliman, B. R., Hacker, S. D., Wolanski, E., Primavera, J., et al. (2008). Coastal ecosystem-based management with nonlinear ecological functions and values. Science 319, 321-323. doi: 10.1126/science.1150349

Cannicci, S., Lee, S. Y., Bravo, H., Cantera-Kintz, J. R., Dahdouh-Guebas, F., Fratini, S., et al. (2021). A functional analysis reveals extremely low redundancy in global mangrove invertebrate fauna. Proc. Natl. Acad. Sci. U. S. A. 118:e2016913118. doi: 10.1073/pnas.2016913118

Chevalier, J. M., and Buckles, D. (2013). Participatory Action Research: theory and Methods for Engaged Inquiry, 1st ed. Abingdon: Routledge publishers.

Chong, V. C. (2006). Sustainable utilization and management of Mangrove ecosystems of Malaysia. Aquat. Ecosyst. Health Manag. 9, 249-260. doi: 10.1080/ 14634980600717084

\section{FUNDING}

JH was funded by the Belgian National Research Fund (FRSFNRS). The fieldwork was partly supported by VLIR-UOS. MQ-Z was funded by DAAD.

\section{ACKNOWLEDGMENTS}

We are grateful to all people who have participated in the present survey. We thank to Perak Forestry Department for allowing us to conduct this study. The help rendered by the UMT studentsHaramaini Binti Ariffin, Emilia Hazrina Binti Ashari, Faiz bin Mahamud, Ahmad Jarir Bin Jauhari, and Mr. Muhammad Syafiq bin Abdullah, for language translation is highly appreciated. The logistic support was provided by the INOS, UMT.

\section{SUPPLEMENTARY MATERIAL}

The Supplementary Material for this article can be found online at: https://www.frontiersin.org/articles/10.3389/fevo.2021. 621721/full\#supplementary-material

Costanza, R., and Farber, S. (2002). Introduction to the special issue on the dynamics and value of ecosystem services: integrating economic and ecological perspectives. Ecol. Econ. 41, 367-373. doi: 10.1016/S0921-8009(02)00087-3

Dahdouh-Guebas, F., Hettiarachchi, S., Lo Seen, D., Batelaan, O., Sooriyarachchi, S., Jayatissa, L. P., et al. (2005). Transitions in ancient inland freshwater resource management in Sri Lanka affect biota and human populations in and around coastal lagoons. Curr. Biol. 15, 579-586. doi: 10.1016/j.cub.2005.01.053

Dahdouh-Guebas, F., Hugé, J., Abuchahla, G. M. O., Cannicci, S., Jayatissa, L. P., Kairo, J. G., et al. (2021). Reconciling nature, people and policy in the mangrove social-ecological system through the adaptive cycle heuristic. Estuar. Coast. Shelf Sci. 248:106942.

Dahdouh-Guebas, F., Mathenge, C., Kairo, J. G., and Koedam, N. (2000). Utilization of mangrove wood products around mida creek (Kenya) amongst subsistence and commercial users. Econ. Bot. 54, 513-527. doi: 10.1007/ BF02866549

DasGupta, R., and Shaw, R. (eds) (2017). Participatory Mangrove Management in a Changing Climate Perspectives from the Asia-Pacific. Japan: Springer publishers.

Din, N., Saenger, P., Jules, P. R., Siegfried, D. D., and Basco, F. (2008). Logging activities in mangrove forests: a case study of Douala Cameroon Logging activities in mangrove forests: a case study of Douala Cameroon. African J. Environ. Sci. Technol. 2, 22-30.

Elangkovan, K. (2012). Minimum Wage Laws in Malaysia: an Answer to the Increasing Rate of Unemployment. Int. J. Acad. Res. Econ. Manag. Sci. 1, $135-146$.

Elster, C. (2000). Reasons for reforestation success and failure with three mangrove species in Colombia. For. Ecol. Manage. 131, 201-214. doi: 10.1016/S03781127(99)00214-5

Feka, Z. N. (2015). Sustainable management of mangrove forests in West Africa: a new policy perspective? Ocean Coast. Manag. 116, 341-352. doi: 10.1016/J. OCECOAMAN.2015.08.006

Feurer, M., Gritten, D., and Than, M. (2018). Community Forestry for Livelihoods: benefiting from Myanmar's Mangroves. Forests 9:150. doi: 10.3390/f9030150

Fontalvo-Herazo, M. L., Piou, C., Vogt, J., Saint-Paul, U., and Berger, U. (2011). Simulating harvesting scenarios towards the sustainable use of mangrove forest plantations. Wetl. Ecol. Manag. 19, 397-407. doi: 10.1007/s11273-011-9224-4

Food and Agriculture Organization (FAO) (2007). The World's Mangroves 19802005 (No. 153). Rome: FAO Forestry Paper. 
Goessens, A., Satyanarayana, B., Van Der Stocken, T., Quispe Zuniga, M., Mohd-Lokman, H., Sulong, I., et al. (2014). Is Matang Mangrove Forest in Malaysia sustainably rejuvenating after more than a century of conservation and harvesting management? PLoS One 9:e105069. doi: 10.1371/journal.pone. 0105069

Grasso, M. (1998). Ecological-economic model for optimal mangrove trade off between forestry and fishery production: comparing a dynamic optimization and a simulation model. Ecol. Model. 112, 131-150. doi: 10.1016/S03043800(98)00076-3

Hamdan, O., Hasmadi, I. M., and Aziz, H. K. (2013). Mangrove carbon stock assessment by optical satellite imagery. J. Trop. For. Sci. 25, 554-565.

Hamilton, S. E., and Friess, D. A. (2018). Global carbon stocks and potential emissions due to mangrove deforestation from 2000 to 2012. Nat. Clim. Change 8, 240-244. doi: 10.1038/s41558-018-0090-4

Hugé, J., Vande Velde, K., Benitez-Capistros, F., Japay, J. H., Satyanarayana, B., Nazrin Ishak, M., et al. (2016). Mapping discourses using Q methodology in Matang Mangrove Forest. Malaysia. J. Environ. Manage. 183, 988-997. doi: 10.1016/j.jenvman.2016.09.046

Ibharim, N. A., Mustapha, M. A., Lihan, T., and Mazlan, A. G. (2015). Mapping mangrove changes in the Matang Mangrove Forest using multi temporal satellite imageries. Ocean Coast. Manag. 114, 64-76. doi: 10.1016/j.ocecoaman. 2015.06.005

Ismail, S. M., Muda, A., Ujang, R., Budin, K. A., Lim, K. L., Rosli, S., et al. (2005). Sustainable Management of Matang Mangroves: 100 years and Beyond. Kuala Lumpur: Malaysia: Forestry Department Peninsular Malaysia.

Jennerjahn, T. C. (2020). Relevance and magnitude of'Blue Carbon'storage in mangrove sediments: carbon accumulation rates vs. stocks, sources vs. sinks. Estuar. Coast. Shelf Sci. 247:107027. doi: 10.1016/j.ecss.2020.1 07027

Juliana, W. A. W., Razali, M. S., and Latiff, A. (2014). "Distribution and Rarity of Rhizophoraceae" in Peninsular Malaysia in Mangrove Ecosystems of Asia. eds I. Faridah-Hanum, A. Latiff, K. Hakeem, and M. Ozturk (New York: Springer). 23-36. doi: 10.1007/978-1-4614-8582-7_2

Jusoff, K. (2013). Malaysian Mangrove Forests and their Significance to the Coastal Marine Environment. Polish J. Environ. Stud. 22, 979-1005.

Kairo, J. G., Bosire, J., and Koedam, N. (2001). Restoration and management of mangrove systems - a lesson for and from the East African region. South African J. Bot. 67, 383-389.

Keith, D. A., Rodriguez, J. P., Rodriguez-Clark, K. M., Nicholson, E., Aapala, K., Alonso, A., et al. (2013). Scientific Foundations for an IUCN Red List of Ecosystems. PLoS One 8:e62111. doi: 10.1371/journal.pone.00 62111

Kodikara, K. A. S., Mukherjee, N., Jayatissa, L. P., Dahdouh-Guebas, F., and Koedam, N. (2017). Have mangrove restoration projects worked? An in-depth study in Sri Lanka. Restor. Ecol. 25, 705-716. doi: 10.1111/rec.12492

Kong, S. H., Loh, S. K., Bachmann, R. T., Rahim, S. A., and Salimon, J. (2014). Biochar from oil palm biomass: a review of its potential and challenges. Renew. Sustain. Energy Rev. 39, 729-739. doi: 10.1016/j.rser.2014.07.107

Kustanti, A., Nugroho, B., Kusmana, C., Darusman, D., Nurrochmat, D., Krott, M., et al. (2014). Actor, Interest and Conflict in Sustainable Mangrove Forest Management-A Case from Indonesia. Int. J. Mar. Sci. 4, 150-159. doi: 10.5376/ ijms.2014.04.0016

Lee, S. Y., Hamilton, S., Barbier, E. B., Primavera, J., and Lewis, R. R. (2019). Better restoration policies are needed to conserve mangrove ecosystems. Nat. Ecol. Evol. 3, 870-872. doi: 10.1038/s41559-019-0861-y

Lee, S. Y., Primavera, J. H., Dahdouh-Guebas, F., Mckee, K., Bosire, J. O., Cannicci, S., et al. (2014). Ecological role and services of tropical mangrove ecosystems: a reassessment. Glob. Ecol. Biogeogr. 23, 726-743. doi: 10.1111/geb.12155

Lovelock, C. E., Cahoon, D. R., Friess, D. A., Guntenspergen, G. R., Krauss, K. W., Reef, R., et al. (2015). The vulnerability of Indo-Pacific mangrove forests to sea-level rise. Nature 526, 559-563. doi: 10.1038/nature15538

Lucas, R., Otero, V., Van De Kerchove, R., Lagomasino, D., Satyanarayana, B., Fatoyinbo, T., et al. (2020a). Monitoring Matang's Mangroves in Peninsular Malaysia through Earth observations: a globally relevant approach. Land Degrad. Dev. 32, 354-373. doi: 10.1002/ldr.3652

Lucas, R., Van De Kerchove, R., Otero, V., Lagomasino, D., Fatoyinbo, L., Hamden, O., et al. (2020b). Structural characterisation of mangrove forests achieved through combining multiple sources of remote sensing data. Remote Sens. Environ. 237:111543. doi: 10.1016/j.rse.2019.111543

Martínez-Espinosa, C., Wolfs, P., Veldea, K. V., Satyanarayana, B., DahdouhGuebasa, F., and Hugé, J. (2020). Call for a collaborative management at Matang Mangrove Forest Reserve, Malaysia: an assessment from local stakeholders' view point. Forest Ecol. Manag. 458:117741. doi: 10.1016/j.foreco.2019.11 7741

Mašek, O. (2013). "Biochar and Carbon Sequestration" in Fire Phenomena and the Earth System: an Interdisciplinary Guide to Fire Science. ed. C. M. Belcher (UK: John Wiley \& Sons). 309-322.

Mcleod, E., and Salm, R. V. (2006). Managing Mangroves for Resilience to Climate Change (No. 2), IUCN Resilience Science Group Working Paper Series. Switzerland: IUCN, Gland.

Ministry of Human Resources [MHR] (2020). Minimum Wages Order 2020 by the Fedaral Goverenment Gazette of Malaysia. Available online at: http:// minimumwages.mohr.gov.my/index.php/ms/ (Accessed September 03, 2021)

Moreira dos Santos, N., and Lana, P. (2017). Present and past uses of mangrove wood in the subtropical Bay of Paranaguá (Paraná. Brazil). Ocean Coast. Manag. 148, 97-103. doi: 10.1016/j.ocecoaman.2017.07.003

Moriizumi, Y., Matsui, N., and Hondo, H. (2010). Simplified life cycle sustainability assessment of mangrove management: a case of plantation on wastelands in Thailand. J. Clean. Prod. 18, 1629-1638. doi: 10.1016/j.jclepro.2010.07.017

Mukherjee, N., Zabala, A., Huge, J., Nyumba, T. O., Adem Esmail, B., and Sutherland, W. J. (2018). Comparison of techniques for eliciting views and judgements in decision-making. Methods Ecol. Evol. 9, 54-63. doi: 10.1111/ 2041-210X.12940

Nguyen, T. P., Luom, T. T., and Parnell, K. E. (2017). Mangrove allocation for coastal protection and livelihood improvement in Kien Giang province, Vietnam: constraints and recommendations. Land. Use Policy 63, 401-407. doi: 10.1016/j.landusepol.2017.01.048

Noakes, D. S. P. (1952). A Working Plan for the Matang Mangrove Forest Reserve Perak. Malaysia: Forestry Department of Perak.

Palacios Peñaranda, M. L., Cantera Kintz, J. R., and Peña Salamanca, E. J. (2019). Carbon stocks in mangrove forests of the Colombian Pacific. Estuar. Coast. Shelf Sci. 227:106299. doi: 10.1016/j.ecss.2019.106299

Primavera, J. H., and Esteban, J. M. A. (2008). A review of mangrove rehabilitation in the Philippines: successes, failures and future prospects. Wetl. Ecol. Manag. 16, 345-358. doi: 10.1007/s11273-008-9101-y

Rahman, M. A. A., and Asmawi, M. Z. (2016). Local Residents' Awareness towards the Issue of Mangrove Degradation in Kuala Selangor, Malaysia. Procedia - Soc. Behav. Sci. 222, 659-667. doi: 10.1016/j.sbspro.2016.05.222

Reed, M. S., Graves, A., Dandy, N., Posthumus, H., Hubacek, K., Morris, J., et al. (2009). Who's in and why? A typology of stakeholder analysis methods for natural resource management. J. Environ. Manage. 90, 1933-1949. doi: 10.1016/ j.jenvman.2009.01.001

Richards, D. R., and Friess, D. A. (2016). Rates and drivers of mangrove deforestation in Southeast Asia, 2000-2012. Proc. Natl. Acad. Sci. 113, 344-349. doi: $10.1073 /$ pnas.1510272113

Rogers, K., Kelleway, J. J., Saintilan, N., Megonigal, J. P., Adams, J. B., Holmquist, J. R., et al. (2019). Wetland carbon storage controlled by millennial-scale variation in relative sea-level rise. Nature 567, 91-95. doi: 10.1038/s41586-0190951-7

Roy, A. K. D. (2016). Local community attitudes towards mangrove forest conservation: lessons from Bangladesh. Mar. Policy 74, 186-194. doi: 10.1016/j. marpol.2016.09.021

Satyanarayana, B., Bhanderi, P., Debry, M., Maniatis, D., Foré, F., Badgie, D., et al. (2012). A Socio-Ecological Assessment Aiming at Improved Forest Resource Management and Sustainable Ecotourism Development in the Mangroves of Tanbi Wetland National Park. The Gambia, West Africa. Ambio 41, 513-526. doi: 10.1007/s13280-012-0248-7

Satyanarayana, B., Mulder, S., Jayatissa, L. P., and Dahdouh-Guebas, F. (2013). Are the mangroves in the Galle-Unawatuna area (Sri Lanka) at risk? A socialecological approach involving local stakeholders for a better conservation policy. Ocean Coast. Manag. 71, 225-237. doi: 10.1016/j.ocecoaman.2012.10. 008

Sievers, M., Pearson, R. M., Turschwell, M. P., Bishop, M. J., Bland, L., Brown, C. J., et al. (2020). Integrating outcomes of IUCN red list of ecosystems assessments 
for connected coastal wetlands. Ecol. Indicat. 116:106489. doi: 10.1016/j.ecolind. 2020.106489

Sillanpää, M., Vantellingen, J., and Friess, D. A. (2017). Vegetation regeneration in a sustainably harvested mangrove forest in West Papua. Indonesia. For. Ecol. Manage. 390, 137-146. doi: 10.1016/j.foreco.2017. 01.022

Sippo, J. Z., Santos, I. R., Sanders, C. J., Gadd, P., Hua, Q., Lovelock, C. E., et al. (2020). Reconstructing extreme climatic and geochemical conditions during the largest natural mangrove dieback on record. Biogeosciences 17, 4707-4726. doi: 10.5194/bg-17-4707-2020

Siti Marshita, B. M. (2013). Minimum wage in Malaysia: the challenge on the implementation of the law. Int. J. Bus. Econ. Law 3, 30-37.

Stone, K., Bhat, M., Bhatta, R., and Mathews, A. (2008). Factors influencing community participation in mangroves restoration: a contingent valuation analysis. Ocean Coast. Manage. 51, 476-484. doi: 10.1016/j.ocecoaman.2008. 02.001

The Charcoal Project [TCP] (2021). Diverse Options Exist for Securing Sustainable Feedstock for Charcoal in the Global South. Available online at: https://www.charcoalproject.org/wp-content/uploads/2021/03/PolicyBrief-Sustainable-Charcoal-Feedstocks-14.pdf [Accessed September 03, 2021]

Thorat, S. (2014). "Tackling Social Exclusion and Marginality for Poverty Reduction: indian Experiences" in Marginality. (eds) J. von Braun and F. Gatzweiler (Dordrecht: Springer publsihers). 205-219. doi: 10.1007/978-94007-7061-4_13

United Nations Environment Programme - World Conservation and Monitoring Centre [UNEP-WCMC] (2006). In the Front Line: shoreline Protection and Other Ecosystem Services from Mangroves and Coral Reefs. UNEP-WCMC Biodiversity Series 24. UK: Cambridge Printers.

United Nations Environment Programme [UNEP] (2014). Where will the water go? Impacts of accelerated glacier melt in the Tropical Andes. Environ. Dev. 10, 108-119. doi: 10.1016/j.envdev.2013.10.001
Walters, B. B., Rönnbäck, P., Kovacs, J. M., Crona, B., Hussain, S. A., Badola, R., et al. (2008). Ethnobiology, socio-economics and management of mangrove forests: a review. Aquat. Bot. 89, 220-236. doi: 10.1016/j.aquabot.2008.02.009

Wolswijk, G., Satyanarayana, B., Dung, L. Q., Siau, Y. F., Ali, A. N. B., Saliu, I. S., et al. (2020). Distribution of mercury in sediments, plant and animal tissues in Matang Mangrove Forest Reserve, Malaysia. J. Hazard. Mater. 387:121665. doi: 10.1016/j.jhazmat.2019.121665

Wong, S. L. (2005). Matang Mangroves: a Century of Sustainable Management. Malaysia: Forestry Department Peninsular Malaysia.

Young, J. C., Rose, D. C., Mumby, H. S., Benitez-Capistros, F., Derrick, C. J., Finch, T., et al. (2018). A methodological guide to using and reporting on interviews in conservation science research. Methods Ecol. Evol. 9, 10-19. doi: $10.1111 / 2041-210 X .12828$

Conflict of Interest: The authors declare that the research was conducted in the absence of any commercial or financial relationships that could be construed as a potential conflict of interest.

Publisher's Note: All claims expressed in this article are solely those of the authors and do not necessarily represent those of their affiliated organizations, or those of the publisher, the editors and the reviewers. Any product that may be evaluated in this article, or claim that may be made by its manufacturer, is not guaranteed or endorsed by the publisher.

Copyright (c) 2021 Satyanarayana, Quispe-Zuniga, Hugé, Sulong, Mohd-Lokman and Dahdouh-Guebas. This is an open-access article distributed under the terms of the Creative Commons Attribution License (CC BY). The use, distribution or reproduction in other forums is permitted, provided the original author $(s)$ and the copyright owner(s) are credited and that the original publication in this journal is cited, in accordance with accepted academic practice. No use, distribution or reproduction is permitted which does not comply with these terms. 